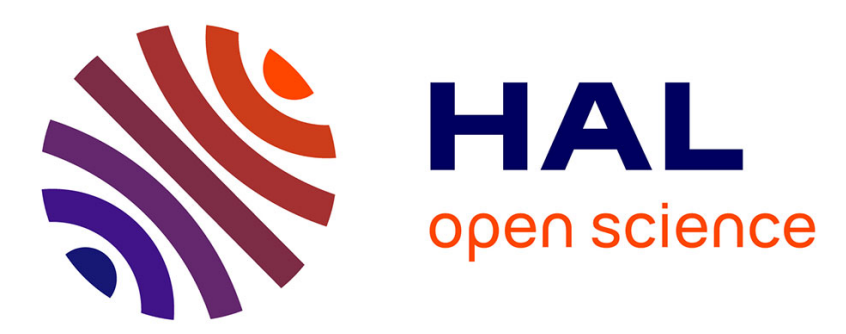

\title{
A risk perspective on Chinese student migration in France

\author{
Yong $\mathrm{Li}$
}

\section{To cite this version:}

Yong Li. A risk perspective on Chinese student migration in France. Fred Dervin. Chinese educational migration and student-teacher mobilities: Experiencing otherness, Palgrave Macmillan, 2015. halshs02023863

\section{HAL Id: halshs-02023863 \\ https://shs.hal.science/halshs-02023863}

Submitted on 18 Oct 2019

HAL is a multi-disciplinary open access archive for the deposit and dissemination of scientific research documents, whether they are published or not. The documents may come from teaching and research institutions in France or abroad, or from public or private research centers.
L'archive ouverte pluridisciplinaire HAL, est destinée au dépôt et à la diffusion de documents scientifiques de niveau recherche, publiés ou non, émanant des établissements d'enseignement et de recherche français ou étrangers, des laboratoires publics ou privés. 
A risk perspective on Chinese student migration in France

1

Yong Li

University of Rouen

Li Yong is a PhD candidate in the Department of Sociology at the University of Rouen-Haute Normandie in France. He was previously a Teaching and Research Temporary Attaché (Attaché temporaire d'enseignement et de recherche) in the Sociology Department of the University of Rouen. His $\mathrm{PhD}$ thesis and publications focus on the labour market experiences of Chinese students in France and their decisions regarding whether to return to China or to remain in the host country. 


\begin{abstract}
Over the past two decades, the global flow of Chinese student migration has changed significantly. Overseas Chinese students are torn between the desire to return to China and a fear of returning. Based on a study of employability among Chinese students who arrived in France in the 2000 s, the study adopts a sociological perspective of risk in analysing student mobility. The findings show that risk and uncertainty shape the migration process for Chinese students. Overseas Chinese students are engaged in an individualisation process in which they are vulnerable to social change, and they must address risk in different areas of life upon graduation. Thus, many students find achieving a traditional ideal of success difficult, and they must postpone their return to China.
\end{abstract}

Key words: student mobility, study abroad, labour market experiences, migration decisions, risk, uncertainty, individualisation, China, France 


\section{INTRODUCTION}

Since the late 1990s, French campuses have observed an influx of Chinese students. From 1998 to 2005 , the number of Chinese students in French public universities increased twelvefold, ten times more than the increase in the number of other foreign students (Fabre \& Guillerm, 2007). Today, France is the seventh most popular country as a destination for Chinese students. Traditionally, the migration of Chinese students has been studied in terms of students' return (or not) to their home country after the complete their studies. In France, recent studies show that Chinese students possess a strong desire to return to their country of origin - a stronger desire than other foreign students - yet have a fear of returning (Ennafaa \& Paivandi, 2008a, 2008b). It may appear puzzling that many Chinese students want to remain abroad after completing their education despite an unfavourable economic climate that does not favour their integration into the labour market.

This study of employability among Chinese students who arrived in France in the 2000s reveals that the overseas experience of Chinese students may be analysed from a sociological perspective of risk. The central hypothesis is threefold: 1) risk and uncertainty are structural elements of the immigration process; 2) the risk society and individualisation thesis of Ulrich Beck (Beck, 1992; Beck \& Beck-Gernsheim, 2002) offers an appropriate framework with which to analyse recent developments in Chinese students' migration to Western countries; and 3) the post-graduation experiences of Chinese students in France correspond to an individualisation of risk management. These students find achieving a traditional ideal of success increasingly difficult. 
This chapter is largely conceptual but uses data collected between 2007 and 2012 from biographical interviews with Chinese graduate students who remained in France after their college studies. Seventeen Chinese employees ( 9 women and 8 men) working in the UpperNormandy region (comprising the northern départements of Eure and Seine-Maritime and encompassing the northeastern portion of Normandy) or in Paris were interviewed with the "snowball" method. The respondents were between 25 and 33 years of age, arrived in France after 2000, and worked there for less than five years.

\section{RETURN AND NON-RETURN OF STUDENTS: CURRENT TRENDS AND ISSUES}

Return to the home country is a common theme in modern migrant narratives; however, the meaning of such a return varies across generations, and the possibility of return strongly depends on the legal status and qualifications of migrants as well as the socioeconomic and political environments of migrants' home countries (Al-Rasheed, 1994; Bolognani, 2007; Sinatti, 2011; Zetter, 1999). For some migrants, their return to their home country is indefinitely postponed, potentially developing into a myth (Sayad, 2006).

For the Chinese students interviewed for this study who arrived in France in the 2000s, a successful return to China is often the goal of their venture because it justifies socioeconomically motivated migration. However, some graduates find realising their dream difficult because a migration journey is characterised by risk and uncertainty.

For over half a century, the return of foreign students to their countries of origin has been a concern for both researchers and policymakers. The question now assumes a special meaning in France, where the government is attempting to integrate foreign students into its general immigration policy (Deneuve, 2001; Héran, 2007; Héran, Aoudai, \& Richard, 2002). Discussions on this subject are informed by ethical considerations (Dumitru, 2009), changes in 
theoretical perspectives, and political orientations. The study of Chinese student mobility must therefore encompass several recent developments.

First, the global flow of Chinese student migration has changed significantly over the last two decades. Since China's opening up in 1978, most Chinese students who have gone overseas to study have decided to stay remain the developed world. However, since 2000, the number of students returning to China has been increasing significantly. In the United States, this movement is illustrated by "a sustained drop in the number of doctoral students from China ... who planned to remain in the United States beginning in the late 1990s" (Saravia \& Miranda, 2004, p. 608). In Europe, the number of Chinese graduates returning to their home country has also increased in recent years. This increase in returning Chinese students is partly due to the sharp decrease in job opportunities owing the economic slowdown in the West. In addition, China's surging economy and unprecedented investment in its innovative system have created favourable conditions at home (Hao \& Welch, 2012; Welch \& Hao, 2013). Further, beyond automatic market regulation, the Chinese state has played an important role in this movement by mobilising discursive, political, and financial resources to motivate highly skilled scientists and professionals to return to China (Jonkers, 2010; Nyíri, 2001, 2002; Welch \& Cai, 2011; Welch \& Hao, 2013; Zweig, 2006). If the feeling of duty to serve the nation appears prevalent among the Chinese intellectual diaspora (Liu, 2005; Nyíri, 2010; Nyíri \& Breidenbach, 2005), the meaning of returning home has radically changed over the last few decades. For the "sea turtles" of the reform era (Wang, 2005, 2007, 2009), unlike twenty years ago, returning to China no longer means sacrificing one's professional future for the nation and subscribing to a particular ideological position. By joining a prosperous economy at home, returnees may find that their self-interest (whether material or symbolic) and the needs of the nation coincide (Cai, 2012). 
Second, this change in the flow of migration raises questions regarding the country of origin and the migrants themselves, particularly regarding capitalising on foreign experiences in the Chinese labour market. In the earlier era of China's opening, simply returning with a foreign degree was sufficient to ensure a good job. Now, however, with the increasing number of returnees and an increase in graduate unemployment (Lian, 2009; Rocca, 2007), merely having a foreign degree is no longer sufficient. Today's labour market in China is adopting an increasingly mature, discriminating attitude towards recruiting international graduates (Hao \& Welch, 2012, p. 243). Overseas-educated graduates have certain advantages with regard to employment compared with their local counterparts, including much better access to a local $\mathrm{Hukou}^{2}$ in a major Chinese city (e.g., Beijing or Shanghai), which accords returnees more freedom than local graduates in their job-seeking efforts. However, returnees are confronted with problems that their local counterparts do not face, such as striking a balance between the knowledge and attributes that they obtained overseas and their home culture and filling the gap between their wage expectations and the expectations of their employers (Ascencio, 2006; Hao \& Welch, 2012; Welch \& Hao, 2014). If graduates from top-ranking universities with work experience can cater to employers' needs and can succeed in securing higher positions in the labour force, graduates from less recognised higher education institutions, without professional experience, may have difficulty finding a job (Hao \& Welch, 2012; Welch \& Hao, 2014). Every day, dramatic stories of young unemployed returnees generate stronger collective disappointment regarding overseas studies, as illustrated by the popular saying, "The Sea Turtle has become seaweed" (haigui bian haidai). However, recent studies on employability among returnees suggest that a quality international education nevertheless positively influences an individual's career and life in China and that the so-called "devaluation of the sea turtle" has been greatly exaggerated by the media (Hao \& Welch, 2012; Wang, 2012). However, media 
hype has had a real effect on the decisions of Chinese graduates, as students who follow with the news may be fearful of returning to China.

Third, over the last two decades, a "paradigm shift" has changed the manner in which international migration studies and student migration are approached in the social sciences. Because of the contribution of transnationalism, scholars now emphasise movement and mobility as well as the connectivity between the country of origin and the host country as developed by migrants (Schiller, Basch, \& Blanc-Szanton, 1992). In a similar vein, transmigrants maintain significant ties across national borders and live their lives simultaneously in multiple locations (Portes, 2001; Sinatti, 2011). The immigration process is increasingly perceived as circular and reversible rather than as linear and unidirectional. Moreover, the transnational or cosmopolitan character of returning home is emphasised: returning to one's country of origin does not presage the end of migration. A return can be the starting point of new mobility (Baas, 2013; Maillard, 2009; Varrel, 2009). Regarding student migration, the "brain drain" paradigm that was developed in the 1960s has gradually yielded to new paradigms that are characterised by a "connexionist" approach. Since the late 1980s, researchers have attempted to explain that brain drain is not always a definite loss for the country of origin by conceptualising new approaches, such as "brain gain", "transit brain drain", "delayed return", and even "brain mobility". After all, the shifts in academic approaches to migration are rooted in deeper ideological shifts. The nexus of "return migration and development" has always been the basis of reasoning regarding academic approaches to returning student migration (de Haas, 2010). Recent views celebrating migrants as grass-roots actors of development are partially driven by neoliberal ideologies that emphasise individuals' agency rather than the states' responsibility to solve structural problems of development (de Haas, 2012). 
It is interesting to study the ways in which Chinese graduates themselves consider the issues regarding whether to return to China. Although international mobility has become a mundane experience for a growing number of individuals, when they are unsure about the outcomes of mobility in terms of social well-being, they are gripped by disillusion or vague fear. Students thus try to find a safe anchorage (e.g., a geographical, social identity) in our era of "liquid"

modernity (Bauman, 2000). A tension exists between the desire for mobility (be it international or transnational) and the desire for security. Since the 1990s, many studies have observed a "wait and see" strategy among overseas Chinese students. Instead of a definite return to the country of origin, students are seeking secure status in the host country (e.g., a "residence card") while exploring opportunities to return to China (Cheng, 2003; Le Bail, 2006, 2009; Liu-Farrer, 2011; Zweig \& Chen, 1995; Zweig, Fung, \& Han, 2008). In France, naturalised students are actively involved in activities related to China (Cheng, 2002). For such students, the increase in transnational activities can be perceived to result from a collective strategy of risk management in the sense that Chinese students, even if they wish to return to China, prefer to "play it safe". By constructing a social space outside China, and by building overseas networks, Chinese students prepare an exit for themselves if their plan to return fails.

Chinese students' decisions regarding the immigration process thus appear to be affected not only by risk and uncertainty but also material interests, cultural norms, collective representations, and moral obligations. Thus, the concepts of risk and uncertainty can be appropriately included in discussions on the return and non-return of Chinese students in France.

\section{RISK, UNCERTAINTY, AND IMMIGRATION}

Risk shapes and is shaped by migration (Williams \& Baláž, 2012). The concept of risk differs from the concept of uncertainty because the former refers to known uncertainty (Knight, 1921; 
Zinn, 2004). Risk can be understood in terms of the probability of known results. According to Williams and Baláž (2012), a degree of uncertainty always exists in immigration, which comes from two sources: first, migrants' imperfect knowledge about the actual conditions in both the place of departure and possible destinations and, second, the unpredictability of the future. All future changes involve some uncertainty because the likelihood of particular outcomes cannot be known with certainty. Because migration decisions are generally based on at least some knowledge of the destination, decisions are rarely, if ever, made in full ignorance; thus, migration should be understood as a process associated with risk assessment in conditions of partial knowledge (Williams \& Baláž, 2012, pp.168-169).

Risk and uncertainty have been widely discussed in the social sciences (Williams \& Baláž, 2012; Taylor-Gooby \& Zinn, 2006). Sociological theories emphasise the social construction of risk, in which "the individual's perception and response to risk can only be understood against the background of their embeddedness in a sociocultural background and identity as a member of a social group, rather than through individual cognition" (Taylor-Gooby \& Zinn, 2006, p. 37).

Ulrich Beck's theory of the "risk society" (Beck, 1992, 1999) attempts to interpret the growing risk awareness and the societal and individual responses to risk in a general framework of social change within modernity. In the following section, the scope of Beck's argument is outlined, and the relevance of Beck's argument to Chinese students in France is then discussed. As early as the mid-1980s, Beck proclaimed the advent of a second modernity, which was characterised by an increase in modernisation risks and the individualisation of society in the developed West (Beck, 1986, 1992, 1998; Yan, 2010, p. 489). However, this second modern transformation also involves other parts of the world (Beck, 1999, 2007, 2009, 2010; Beck \& Grande, 2010). First, qualitatively different risks are emerging as the unintended side effects of industrialised modernity (Zinn \& Taylor-Gooby, 2006). These side effects are exemplified by the exponential 
growth of new technology, which poses risks that are not fully understood and that cannot be controlled (e.g., smog, radiation, climate change, and genetically modified food). Moreover, such risks have become less temporally and spatially bound, and they display "a tendency to globalisation" (Beck, 1992, p. 13; 1999, 2009). These changes can be understood in terms of a shift from risk to greater uncertainty. Therefore, the traditional methods of risk management such as reliance on family support or insurance do not apply (Williams \& Baláž, 2012).

Second, the emergence of a risk society is connected to the complementary processes of individualisation in the sphere of work, family life, and self-identity. According to Beck, Individualization is understood as a historical process that increasingly questions and tends to break up people's traditional rhythm of life - what sociologists call a normal biography. As a result, more people than ever before are being forced to piece together their own biographies and fit in the components they need as best they can. They find themselves bereft of unquestionable assumptions, beliefs or values and are nevertheless faced with the tangle of institutional controls and constraints which make up the fiber of modern life (welfare state, labor market, education system, etc.). To put it bluntly, the normal life-history is giving way to the do-it-yourself life-history.

(Beck \& Beck-Gernsheim, 2002, pp. 56-57)

Although some sociologists are sceptical about the value of the risk society theory in migration studies, risk theory may provide useful insight into how societies address the risks associated with migration, as long as specific contexts are taken into account.

From this perspective, the recent waves of emigration of upper-middle class Chinese to Western countries may be perceived as a component of reflexive modernisation because these individuals are fleeing not traditional misery but the side effects of compulsive modernisation in China. The typical risks of so-called advanced countries ("new civilisation risks", e.g., 
climate change, ecological destruction, economic inequality, unemployment, global pandemics, an ageing society) coexist with the risks of industrial and traditional societies (Han \& Shim, 2010). According to recent surveys, Chinese citizens are primarily concerned with domestic and social risks, and they tend to consider the risks of everyday life (e.g., poverty, traffic accidents, problems with obtaining care for illnesses, difficulties in accessing housing) to be the most serious risks (N. Liu, 2009; Y. Liu, 2009). Thus, among the "push" factors of this emigration of professional and entrepreneurial Chinese to the "safe haven" of the West, the risks generated by the "deficiencies of modernity" are the most significant (e.g., food poisoning, health system crises, soaring real estate prices).

The next section of the paper focuses on Beck's individualisation theory. This framework moves the discussion from the "cataclysmic democracy" of catastrophic environmental risks to the complexity of risk in everyday life (Williams \& Baláž, 2012, p.173) and the ways in which individuals address these risks.

\section{CHINESE STUDENT MOBILITY AS AN INDIVIDUALISATION PROCESS}

Discussing the individualisation process on the institutional level, Beck describes this concept in three dimensions:

Disembedding, removal from historically prescribed social forms and commitments in the sense of traditional contexts of dominance and support (the 'liberating dimension'); the loss of traditional security with respect to practical knowledge, faith and guiding norms (the 'disenchantment dimension'); and - here the meaning of the word is virtually turned into its opposite - re-embedding, a new type of social commitment (the 'control' or 'reintegration dimension') (Beck, 1992, p. 128) (italics in original). 
In the text that follows, this model is used to interpret the recent trends in Chinese student migration as an individualisation process.

\section{Disembedding, from state assignment to market competition}

The democratisation of overseas studies, promoting self-financing education since the end of the 1990s, implies a transfer of responsibility for education investment from the state to young people and their families (Pan, 2011), which should be perceived in light of a redefinition of state-society-individual relationships in late socialist China (Hoffman, 2006, 2010; Yan, 2010). Before the 1980s, in the era of the planned economy, Chinese university graduates were assigned jobs upon graduation by the government in a top-down process, which guaranteed them a job but determined where they should live and what they should do (Hao \& Welch, 2012; Hoffman, 2010). After the reform and opening of China in the 1970s, in the first period of student migration, government-sponsored overseas studies prevailed, in which the goals, type of training, duration of overseas stay, and future jobs of students were arranged by the state. The period since the early 1990s has witnessed all forms of privatisation of property, labour, and the self (Zhang \& ONG, 2008). The state has been moving towards more and less "distanced" modes of governing (Rose, 1996) such as marketing the labour distribution, fostering a self-enterprising ethic, and emphasising individual choice and autonomy rather than state distribution, as illustrated most explicitly by patriotic professionalism (Hoffman, 2006, 2010). The government gradually loosened its control over graduates, which induced students to respond more readily to the needs of a rapidly changing labour market by finding jobs on their own. Although finding a job upon graduation was previously difficult for some students, the rapid expansion of the higher education system in 1998 has rendered finding a job extremely difficult for many of today's graduates (Hao \& Welch, 2012, p. 247). In this context, students 
and their families increasingly regard international education is by as a rational investment in human capital to meet the demands of a labour market that is becoming increasingly competitive.

Accordingly, China has experienced a Chuguo Re (going-out fever) since the government loosened the restrictions on self-financed overseas studies in the late 1990s (Xiang, 2003). The privatisation of studying abroad has also privatised the risks that are involved in international educational mobility for students and their families. Individuals must make choices and decisions regarding diverse countries of destination, universities, degree programmes, and so forth, based on their partial knowledge of both the host country and the home country. They must take the entire responsibility for failures, delays, and incidents that affect them during their journey.

However, the Chinese students who were interviewed for this study tended to have positive perceptions of the risks posed by migration during their overseas study project. They appear to be what Lyng (2008) called edgeworkers. They believe that overseas studies not only increase their self-esteem through their ability to manage these risks successfully but also contribute to peer esteem. In addition, acquiring another language and experiencing international exposure improve the value of their curriculum vitae on the labour market. Overseas study experiences may raise a "normal" biography via geographical and social mobility into an elective or "do-ityourself” biography (King \& Ruiz-Gelices, 2003, p. 232). Moreover, our respondents perceive the risks in migration as a source of excitement that invigorates an otherwise well-adjusted and predictable life. Experiencing another lifestyle and confronting risks on one's own in a foreign country are two common themes of the "romanticism" of studying abroad, as indicated in the narratives of students and in the popular literature on this subject in China (Hu, 2004, pp. 152156). 


\section{Disenchantment, the loss of traditional certainty and security}

As students venture into a globalised life-world, the traditional security with respect to practical knowledge, faith, and guiding norms loses a large portion of its relevance. During their stay abroad, the students must set goals for themselves, build their own life courses, and give meaning to their experiences, sometimes under pressure and with conflicting constraints. However, risk and uncertainty do not come only from the "difficulties of integration" into the host society as foreigners. Rather, risk and uncertainty primarily derive from the centrifugal forces of the individualisation process in the host society itself (Castel, 2009), as well as the crisis of employment and higher education. In European countries, the labour markets are becoming more flexible and precarious, creating forms of underemployment and economic niches that are saturated with risks. The traditional work-oriented training systems are struggling to survive. Some educational degrees are "deadlocks" because they lead nowhere in the labour market. When Chinese graduates try to enter the French labour market, they go through a "twilight zone" of underemployment subject to risks, including temporary unemployment, few jobs on the labour market, additional training, part-time jobs, and unpaid internships.

Over the last ten years, official discourse in China suggests that Chinese students should first accumulate adequate overseas work experience before returning to China, although in the context of the economic recession in Europe, a great number of students have no chance of finding a job related to their initial training. Thus, with the overall decrease in the volume of work on the French labour market, a large number of Chinese graduates are unlikely to find work after their training in the host country despite all their good intentions. Some graduates cannot even find an internship, and they are hence forced to seek opportunities in China. This 
study shows that many Chinese graduates find themselves trapped in a "double-bind" between the need to succeed and the inability to succeed in the prescribed forms (Roulleau-Berger, 2007). With the increase in foreign degrees in China, the benefit of overseas studies should not be taken for granted because the extent of the benefit largely depends on an individual's personal trajectory. The Chinese graduates who were interviewed for this study were increasingly feeling the need to combine their foreign degrees with other elements (e.g., overseas work experience, financial capital, social relations) to find a good job when they return to China. For instance, Liu, a 35-year-old tourist professional with a $\mathrm{PhD}$ in biology in Paris, discussed the drastic changes in China's labour market that forced him to abandon his initial return project:

Those who can find a job in China are not satisfied, and they are not sure about their future. They decide to go abroad and use foreign training as a means or a shortcut to success. They can study for two or three years abroad just to get covered with gold, to become a true piece of gold on their return to China. Many people have gone abroad with this idea. But the reality has changed. Today, when someone returns to China, the situation she faces is not comparable to that of 10 years ago. The labour market has changed dramatically! Companies put a big question mark on the value of diplomas obtained abroad.

\section{Re-embedding, in search of new forms of social integration}

The re-embedding dimension refers to the interactions of migrants with new forms of social control or social integration programmes established in both the country of origin and the host country. In France, the government has sought to implement a selective immigration policy in recent years to identify "good immigrants" who can contribute to the collective good. However, by asking immigrants to demonstrate their willingness to integrate and their adaptability to a 
greater extent, this policy can burden people who are already weakened by various difficulties (e.g., linguistic, economic, professional) (Soysal, 2012). Conversely, China has increasingly focused on a "diaspora option" to allow greater freedom of movement internationally and to deploy Chinese nationalism in an effort to entice highly skilled overseas Chinese to bring their skills back home, even if not permanently (Meyer, 2001; Welch \& Zhen, 2008; Zweig, 2006; Zweig et al., 2008). At the beginning of the new millennium, in response to the increase in the Chinese knowledge diaspora, China's policy shifted direction from huiguo fuwu (return and serve the homeland) to the more flexible weiguo fuwu (serve the homeland) by implementing an array of Key Overseas Talent Recruitment schemes targeting the large pool of highly talented overseas Chinese. To take advantage of this new climate, top universities have introduced nonresident fellowship schemes, sometimes termed yaling moshi (dumbbell model), which encourage joint appointments in China and abroad (Cai, 2012; Welch \& Cai, 2011; Welch \& Hao, 2013). Although it grants various privileges to excellent overseas talent, the state stipulates that ordinary Chinese students provide for their own futures by participating in market competition, which is already quite fierce in China (Pan, 2011; Xiang, 2011).

In this new global context, the question of who is and who is not eligible for membership and rights in national communities is increasingly perceived in terms of personal skills, experience, disposition, and chance. From the perspective of a life course, some transitions in the migration journey (e.g., from school to work) are highly significant in initiating advantageous or disadvantageous life course developments. Some transitions lead to cumulative processes in the subsequent life course and, eventually, path dependence (Wingens, de Valk, Windzio, \& Aybek., 2011, p. 13). Student migration thus becomes a continuous process of differentiation and individualisation.

In this context, young returnees who spend a number of years abroad developing some mastery of Western knowledge and culture often face issues reintegrating into their home society. Some 
returnees struggle with effectively combining the notion of "living for others" with the notion of "living for oneself". Although they are increasingly dependent on the employment market, they nevertheless face traditional familial pressure and duties, friendship reciprocity, and social norms. Other returnees struggle with the choice of whether to work in state, private, or foreign enterprises or whether to start their own businesses. Returnees also vacillate between wanting to fulfil their individual aspirations and wanting to meet their sense of social responsibility (i.e., to support the nation). Hoffman (2006) argues that young Chinese professionals harbour neoliberal ideas of self-development as well as late-socialist patriotism. One can sip a Starbucks latte and work for a foreign company while also caring for the nation and exalting nationalism (Welch \& Hao, 2013).

\section{Studying in France and afterwards? Problematic transitions}

This section examines the dilemma that many Chinese students face regarding the dissonance between a traditional ideal of success and the students' new conditions in a global risk society that hamper the realisation of this ideal. The ideal of success is a concept that has emerged from the analysis of the students' interview responses. It is a polysemic notion. First, the respondents view overseas studies as a self-development and self-transformation enterprise (Hoffman, 2006, 2010) that both improves one's human capital (i.e., being more competitive, performing better) and cultivates oneself (i.e., being more cultured, open-minded, cosmopolitan). Second, the interviewees view their overseas experiences to foster their social advancement. These two aspects are closely linked: self-transformation explains one's career advancement; however, self-fulfilment becomes meaningful only when it permits upward social mobility.

For young Chinese students who are engaged such a career advancement project, the success of this project is measured by a double comparison: first, a comparison with oneself, as 
individuals claim to have obtained a more favourable position through overseas studies than they would have occupied had they remained in China, and second, a comparison with others, as returnees are expected to surpass non-migrant members of their original social milieu (e.g., university friends or former business colleagues).

This ideal of success influenced the Chinese graduates' decisions throughout the immigration process. For the interviewees in this study, returning to China could be synonymous with a triumphant homecoming. Graduates justify returning to China by their career ambitions ("I can reach executive positions only in China"), cultural convenience ("I am Chinese; I feel more comfortable living in China"), and family attachment ("There is a Chinese saying: 'When parents are alive, do not travel to distant lands"'). According to some respondents, had they wanted to settle permanently in a foreign country, they would not have come to France, where a residence permit is less accessible than in countries with "immigration traditions" (e.g., Canada, Australia). Conversely, a return to China is possible only when the graduates have already "proven themselves" abroad and when they can expect a prosperous career in China. The Chinese graduates believe that they have a moral obligation to succeed: going abroad nearly always requires important financial support from their parents, and this material and emotional investment must be returned; in short, they must meet the strong expectations of a successful return from all sides (Hu, 2004).

When returning to China becomes both desirable and demanding, the returnee should be well prepared. Thus, most Chinese students in this study consider working for a few years (2 to 5 years) before returning to China. This deferred return project reveals Chinese graduates' awareness of the risks in the context of the country of origin. Graduates must carefully weigh the advantages and disadvantages. Because professional experiences in Western companies are considered rewarding, Chinese students believe that the years of work in France may strengthen their risk resilience in their future mobility. 
Although this "study-short term overseas work experience-return" scheme is a widely held belief among Chinese students in France, the actual development of the life stories of Chinese graduates may greatly differ from this ideal. In a context characterised by risk and uncertainty, any minor incident in the migration process can derail an individual from his originally designed pathway to success.

For Chinese students in France, the postgraduate period involves numerous transitions in different areas of life: a transition into the labour market, a transition into adult life (for those who are single), the choice of a work place, and access to membership in the country of residence. The students would obviously face these transitions in China; however, abroad, the major challenge is to simultaneously manage these dynamics that imply different constraints and expectations.

The notion of timing is important, and it rests on the societal validity of age norms. On-time transitions are generally advantageous, or they at least do not involve negative consequences. Off-time transitions constitute asynchronicities within and between trajectories and produce potentially disadvantageous consequences (Wingens et al., 2011). Student migrants must not only integrate within the labour market but also succeed in a series of transitions in their life course.

Nothing better illustrates the difficulty of this task than the professional integration of Chinese graduates in France. To obtain a job in France, Chinese graduates must overcome all forms of institutional exclusion, ethnic discrimination, and occupational segmentation (Hargreaves, 2007). Many young Chinese engineers find jobs in IT services (computer engineering service companies) that are characterised by high unemployment rates and precarious careers. Indeed, the newcomers to the IT sectors were among the first to lose their jobs in the wake of the financial crisis in France in September 2008. 
The risks in the French labour market generate another risk for Chinese graduates: insecurity of residence in the host country. The recent shift in French immigration policy is marked by increasing restrictions on the residence rights of foreigners (Huddleston, Niessen, Chaoimh, \& White, 2011). In the case of labour migration, the right of residence for migrants is conditional on their work situation. In the first years after leaving a university, the greatest concern of Chinese graduates is securing their stay in France.

Risks and vulnerabilities are also introduced in the private sphere, especially in intimate relationships: how does one build a lasting relationship in the context of uncertainty and mobility? Indeed, the spectre of delaying marriage haunts many Chinese girls who believe that they are already late in starting a family, according to traditional age norms (Li, 2014).

All of these risks are intertwined. In Paris, when a Chinese employee loses her job, she is afraid of being unable to renew her residence permit. She must rethink her entire life project, including plans for marriage, parenthood, a family reunion with her parents, returning to China, and so forth. In contemporary China, public discourse tends to glorify Chinese students abroad as vanguards of modernity and tends to romanticise their migration. The general belief is also that they can succeed in any difficult circumstances (Nyíri, 2010; Xiang, 2011).

Follow-up interviews revealed that many of the interviewees who claimed that they would return to China "in 2 or 3 years" did not actually do so. In a changing global socio-economic landscape, individuals' career plans quickly become obsolete, as exemplified by the vicissitudes of Chinese "expatriates" (waipai). Traditionally, Chinese workers in France seek to acquire the status of returnee (after at least three years of work in France). This status allows them to expect a salary that is two or three times higher than that in China. Individuals who are naturalised in France can return to China with a French expatriation contract (Ascencio, 2006, p. 392). In recent years, deterred by the cost of expatriation, French companies in China are increasingly turning to local candidates. Further, a new strategy involves selecting elite students from China, 
financing their education through a training agreement, and then sending them back to China, of course, with a salary that is standard in China. This "localisation of human resources" tends to flatten the wage gap between the "expatriates" and "locals" and ultimately suppresses most "expatriate" jobs. Chinese engineers and professionals in France seeking an "expatriate" contract find themselves competing with their compatriots in China, who are also brilliant but are less expensive (Li, 2010).

By returning to China, many Chinese graduates wish to take advantage of the qualification differentials between advanced countries and China either to obtain access to higher professional positions (if not a higher salary) than what they may expect in their host countries or to obtain promotions more quickly than their local counterparts. Currently, although important skills differences remain between China and France, the respondents in this study acknowledge that as ordinary employees in France, they have little chance of entering management positions upon their return to China. Indeed, the graduates' physical absence from the Chinese homeland for some years may strain or sever social relationships, leading to a loss of guanxi. The loss of such relationships can be particularly influential in the Chinese context in which changes occur at rapid speed and in which personal relationships play an instrumental role in accessing key positions (Hao \& Welch, 2012; Leung, 2013). Therefore, many respondents fear that after returning to China, they must first prove themselves in subordinate jobs in Chinese companies, just as their local competitors have done. For those who already had professional experience in China and who studied abroad to advance faster than their Chinese counterparts, the idea of returning and competing with local graduates indicates the failure of their initial project. 


\section{CONCLUSION}

This chapter demonstrates that risks and uncertainties are structural elements of the migration phenomenon. The paradigm of risk helps account for new trends in Chinese student immigration in France - and elsewhere. Based on the concept of individualisation, this study theorises about and examines the dynamic interplay between macro-level institutional changes and changes in individual life courses. Thus, with the transformations of the global labour market and immigration system, the migration experiences of Chinese students may be increasingly perceived as a process of risk management in everyday life.

Nevertheless, individualisation does not mean that individuals are freed from societal constraints. Instead, people are more dependent than ever on institutions and are more vulnerable to social change. Institutional crises are increasingly experienced as individual crises, and they must be treated as such. Part of the distress experienced by the Chinese graduates in this study can be explained by the gap between the ideal of success through mobility and the difficulties of the students in achieving their goals in an era of a global risk society.

This article is a first attempt to apply the theory of the risk society to research on student mobility and migration. The study was conducted among only students who remained in France after completing their education in the host country. The interviewees' choices regarding returning to China or remaining in France should be considered "expressed preferences", not a prediction of their eventually actions (Xiao, 2004). Future studies on this subject should focus on risk and uncertainty in immigrants' decision making. Today, the ability to travel across national borders has become critical for individuals, in terms of not only obtaining access to "goods" but also obtaining a more favourable position in the global redistribution of "bads" and risks (Beck, 2013; Curran, 2013a, 2013b). If we recognise that human beings are "reflexive" actors, then people can modify their actions to avoid perceived hazards, although their 
perception of risks is not automatic but socially conditioned (Curran, 2013a). This view questions the effectiveness of Chinese graduates' risk-taking and risk-avoidance strategies. Can these strategies really improve their life chances? Do these strategies enhance their risk position in an unequal risk society? 
References

Al-Rasheed, M. (1994). The myth of return: Iraqi Arab and Assyrian refugees in London. Journal of Refugee Studies, 7(2-3), 199-219. doi: 10.1093/jrs/7.2-3.199

Ascencio, C. (2006). L'insertion professionnelle des Chinois francophones dans les entreprises françaises en Chine [The employment of French-speaking Chinese in French companies in China]. In L. Zheng \& X. Yang (Eds.), France-Chine: Migrations de pensées et de technologies (pp. 389-394). Paris, France: L'Harmattan.

Baas, M. (2013). In-betweeness: The (dis)connection between here and there. The case of Indian student-migrant in Australia. Conserveries Mémorielles, 13. Retrieved from http://cm.revues.org/1468

Bauman, Z. (2000). Liquid moderniy. Cambridge, UK : Polity Press.

Beck, U. (1986). Risikogesellschaft: Auf dem Weg in eine andere Moderne [Risk society: Towards a new modernity]. Frankfurt a. M.: Suhrkamp.

Beck, U. (1992). Risk society: Towards a new modernity. Thousand Oaks, CA: Sage.

Beck, U. (1998). Politics of risk society. In J. Franklin (Ed.), The politics of risk society (pp. 922). Cambridge, UK: Polity Press.

Beck, U. (1999). World risk society. Cambridge, UK: Polity Press.

Beck, U. (2007). Beyond class and nation: Reframing social inequalities in a globalizing world. The British Journal of Sociology, 58(4), 679-705.

Beck, U. (2009). World at Risk. Cambridge, UK: Polity Press.

Beck, U. (2010). Remapping social inequalities in an age of climate change: For a cosmopolitan renewal of sociology. Global Networks, 10(2), 165-181. doi: 10.1111/j.14710374.2010.00281.x 
Beck, U. (2013). Why 'class' is too soft a category to capture the explosiveness of social inequality at the beginning of the twenty-first century. The British Journal of Sociology, 64(1), 63-74. doi: 10.1111/1468-4446.12005

Beck, U., \& Beck-Gernsheim, E. (2002). Individualization: Institutionalized individualism and its social and political consequences. Thousand Oaks, CA: Sage.

Beck, U., \& Grande, E. (2010). Varieties of second modernity: The cosmopolitan turn in social and political theory and research. The British Journal of Sociology, 61(3), 409-443. doi: 10.1111/j.1468-4446.2010.01320.x

Bolognani, M. (2007). The myth of return: Dismissal, survival or revival? A Bradford example of transnationalism as a political instrument. Journal of Ethnic and Migration Studies, 33(1), 59-76. doi: 10.1080/13691830601043497

Cai, H. (2012). Deploying the Chinese knowledge diaspora: A case study of Peking University. Asia Pacific Journal of Education, 32(3), 367-379. doi: $10.1080 / 02188791.2012 .711242$

Castel, R. (2009). La montée des incertitudes : Travail, protections, statut de l'individu [The rise of uncertainty : Work, protection, status of the individual]. Paris, France: Seuil.

Cheng, X. (2002). Non-remaining and non-returning: The Mainland Chinese students in Japan and Europe since the 1970s. In P. Nyíri \& I. R. Saveliev (Eds.), Globalising Chinese migration: Trends in Europe and Asia (pp. 158-172). Hampshire, UK: Ashgate.

Cheng, X. (2003). 当代中国留学生研究 [The study of contemporary overseas Chinese students]. Hong Kong: Hong Kong Press for Social Sciences.

Curran, D. (2013a). Risk society and the distribution of bads: Theorizing class in the risk society. The British Journal of Sociology, 64(1), 44-62. doi: 10.1111/1468-4446.12004

Curran, D. (2013b). What is a critical theory of the risk society? A reply to Beck. The British Journal of Sociology, 64(1), 75-80. doi: 10.1111/1468-4446.12006 
De Haas, H. (2010). Migration and development: A theoretical perspective. International Migration Review, 44(1), 227-264. doi: 10.1111/j.1747-7379.2009.00804.x

De Haas, H. (2012). The migration and development pendulum: A critical view on research and policy. International Migration, 50(3), 8-25. doi: 10.1111/j.1468-2435.2012.00755.x

Deneuve, C. (2001, September). Besoins de main-d'oeuvre des entreprises et recours à l'immigration: Quelles perspectives ? [Companies' needs of manpower and the use of immigration: What prospects?]. In, Migrations internationales. Symposium conducated at the meeting of the Commissariat Général du Plan, Paris, France.

Dumitru, S. (2009). L'éthique du débat sur la fuite des cerveaux [Ethics of the brain drain debate]. Revue Européenne des Migrations Internationales, 25(1), 119-135.

Ennafaa, R., \& Paivandi, S. (2008a). Le non-retour des étudiants étrangers : Au-delà de la « fuite des cerveaux » [Non-return of foreign students : Beyond the "brain drain"]. Formation Emploi, 103(3), 23-39.

Ennafaa, R., \& Paivandi, S. (2008b). Les étudiants étrangers en France: Enquête sur les projets, les parcours et les conditions de vie [Foreign students in France : Survey on projects, life-courses and living conditions]. Paris, France: La Documentation française.

Fabre, J., \& Guillerm, M. (2007). Les étudiants étrangers dans l'enseignement supérieur français: Une croissance soutenue par les Asiatiques [Foreign students in French higher education : A growth sustained by the Asians]. Note d'Information 07-02: Direction de l'évaluation, de la prospective et de la performance [DEPP].

Han, S.-J., \& Shim, Y.-H. (2010). Redefining second modernity for East Asia: A critical assessment. The British Journal of Sociology, 61(3), 465-488. doi: 10.1111/j.14684446.2010.01322.x

Hao, J., \& Welch, A. R. (2012). A tale of sea turtles: Job-seeking experiences of Hai Gui (highskilled returnees) in China. Higher Education Policy, 25(2), 243-260. 
Hargreaves, A. G. (2007). Multi-ethnic France: Immigration, politics, culture and society. New York, NY: Routledge.

Héran, F. (2007). Le temps des immigrés: Essai sur le destin de la population française [The age of immigrants : An essay on the destiny of the French population]. Paris, France: Seuil.

Héran, F., Aoudai, M., \& Richard, J.-L. (2002). Immigration, marché du travail, intégration: Rapport du séminaire présidé par François Héran [Immigration, labour market, integration : Report of the seminar chaired by François Héran]. Report of the meeting of the Commissariat général du plan, Paris, France.

Hoffman, L. (2006). Autonomous choices and patriotic professionalism: On governmentality in late-socialist China. Economy and Society, 35(4), 550-570.

Hoffman, L. (2010). Patriotic professionalism in urban China: Fostering talent. Philadelphia, PA: Temple University Press.

Hu, Y. (2004). Le métier d'étudiant étranger: Le cas des étudiants chinois non spécialistes de français en France [The life of foreign student: The case of Chinese students nonspecialised in French studies in France]. (Unpublished doctoral dissertation). Université Paris 3, Paris, France.

Huddleston, T., Niessen, J., Chaoimh, E. N., \& White, E. (2011). Migrant integration policy index III France. Brussels, Belgium: British Council and Migration Policy Group.

Jonkers, K. (2010). Mobility, migration and the Chinese scientific research system. London, UK: Routledge.

King, R., \& Ruiz-Gelices, E. (2003). International student migration and the European 'Year Abroad': Effects on European identity and subsequent migration behaviour. International Journal of Population Geography 9(3), 229-252.

Knight, F. H. (1921). Risk, uncertainty and profit. Boston, MA: Houghton Mifflin. 
Le Bail, H. (2006). La nouvelle immigration chinoise au Japon: Circulation des élites transnationales et reconfiguration des citoyennetés nationales et locales [The new Chinese immigration in Japan : Movements of transnational elites and reconfiguration of national and local citizenships]. (Unpublished doctoral dissertation). IEP, Paris, France.

Le Bail, H. (2009). La nouvelle immigration chinoise au Japon: Valorisation de la mobilité et espace de vie régional [The new Chinese immigration to Japan: Development of mobilities and regional life space]. In G. Cortès \& L. Faret (Eds.), Les circulations transnationales: Lire les turbulences migratoires contemporaines (pp. 175-186). Paris, France: Armand Colin.

Leung, M. W. H. (2013). 'Read ten thousand books, walk ten thousand miles': Geographical mobility and capital accumulation among Chinese scholars. Transactions of the Institute of British Geographers, 38(2), 311-324. doi: 10.1111/j.1475-5661.2012.00526.x

Li, Y. (2010). Transformation des marchés du travail et dynamiques de l'immigration étudiante chinoise en France [Transformation of labour markets and dynamics of Chinese student immigration in France]. In L. Jacquot, J.-P. Higelé, H. Lhotel, \& C.Nosbonne (Eds.), Formes et structures du salariat: Crise, mutation, devenir (Vol.1, pp.271-283). Nancy, France: Presses Universitaires de Nancy.

Li, Y. (2014). La construction sexuée du parcours d'insertion des diplômés chinois en France [The gendered construction of the integration path of Chinese graduates in France]. In S. Devineau, E. Annoot, \& T. Dezalay (Eds.), Formation, qualification, emploi en Normandie: La construction du genre (pp.127-164). Rouen, France: Presses Universitaires de Rouen et du Havre.

Lian, S. (2009). 蚁族: 大学毕业生聚居村实录 [Ant tribes: A record of inhabited village of university graduates]. Guilin, China: Guangxi Normal University Press. 
Liu, H. (2005). New migrants and the revival of overseas Chinese nationalism. Journal of Contemporary China, 14(43), 291-316.

Liu, N. (2009). Social movements theory: Paradigmatic shifts and its relevance with contemporary Chinese field social research. The journal of Jiangsu Administration Institute, 4, 76-82.

Liu, Y. (2009). Composite risks and composite management in transnational society. Paper presented at a workshop at Kobe University, Japon.

Liu-Farrer, G. (2011). Making careers in the occupational niche: Chinese students in corporate Japan's transnational business. Journal of Ethnic \& Migration Studies, 37(5), 785-803. doi: $10.1080 / 1369183 x .2011 .559718$

Lyng, S. (2008). Edgework, risk and uncertainty. In J. O. Zinn (Ed.), Social theories of risk and uncertainty: An introduction (pp. 106-137). Oxford, UK: Blackwell.

Maillard, D. (2009). Circulation des cerveaux entre la Chine et la Californie: Étudiants, ingénieurs, entrepreneurs et capital-risqueurs chinois dans la Silicon Valley [Brain circulation between China and California : Chinese students, engineers, entrepreneurs and venture capitalists in Silicon Valley]. Paris, France: L'Harmattan.

Meyer, J.-B. (2001). Network approach versus brain drain: Lessons from the diaspora. International Migration, 39(5), 91-110.

Nyíri, P. (2001). Expatriating is patriotic? The discourse on 'new migrants' in the People's Republic of China and the identity construction among recent migrants from the PRC. Journal of Ethnic and Migration Studies, 27, 635-653.

Nyíri, P. (2002). From class enemies to patriots: Overseas Chinese and emigration policy and discourse in the People's Republic of China. In P. Nyíri \& I. R. Saveliev (Eds.), Globalising Chinese migration: Trends in Europe and Asia (pp. 208-241). Hampshire, UK: Ashgate. 
Nyíri, P., \& Breidenbach, J. (Ed.). (2005). China inside out: Contemporary Chinese nationalism and transnationalism. Budapest, Hungary: Central European University Press.

Nyíri, P. (2010). Mobility and cultural authority in contemporary China. Seattle, WA: University of Washington Press.

Pan, S.-Y. (2011). Education abroad, human capital development, and national competitiveness: China's brain gain strategies. Frontiers of Education in China, 6(1), 106-138.

Portes, A. (2001). Introduction: The debates and significance of immigrant transnationalism. Global Networks, 1(3), 181-194.

Rocca, J.-L. (2007, May). Quand la Chine redécouvre la question sociale [When China rediscovers the social question]. Le Monde diplomatique, pp. 10-11.

Rose, N. (1996). Governing "advanced” liberal democracies. In A. Barry, T. Osborne \& N. Rose (Eds.), Foucault and political reason: Liberalism, neo-liberalism, and rationalities of government (pp. 37-64). Chicago, IL: University of Chicago Press.

Roulleau-Berger, L. (2007). Introduction : Nouvelles migrations chinoises et marchés du travail européens [Introduction: New Chinese migrations and European labour markets]. In L. Roulleau-Berger (Eds.), Nouvelles migrations chinoises et travail en Europe (pp. 9-16). Toulouse, France: Presses universitaires du Mirail.

Saravia, N. G., \& Miranda, J. F. (2004). Plumbing the brain drain. Bulletin of the World Health Organization, 82(8), 608-615.

Sayad, A. (2006). L'immigration ou les paradoxes de l'altérité : L'illusion du provisoire (Vol.1) [Immigration or the paradoxes of otherness : The illusion of temporary]. Paris, France: Raisons d'agir. 
Schiller, N. G., Basch, L., \& Blanc-Szanton, C. (1992). Towards a definition of transnationalism. Introductory remarks and research questions. Annals of the New York Academy of Sciences, 645(1), ix-xiv.

Sinatti, G. (2011). 'Mobile transmigrants' or 'unsettled returnees'? Myth of return and permanent resettlement among Senegalese migrants. Population, Space and Place, 17(2), 153-166. doi: 10.1002/psp.608

Soysal, Y. N. (2012). Citizenship, immigration, and the European social project: Rights and obligations of individuality. The British Journal of Sociology, 63(1), 1-21. doi: 10.1111/j.1468-4446.2011.01404.x

Taylor-Gooby, P., \& Zinn, J. O. (Eds.). (2006). Risk in social science. Oxford, UK: Oxford University Press.

Varrel, A. (2009). “Back to Bangalore”. Le retour, une étape de la circulation des migrants indiens les plus qualifiés [Return, a step in the movement of the most skilled Indian migrants]. In G. Cortès \& L. Faret (Eds.), Les circulations transnationales: Lire les turbulences migratoires contemporaines (pp. 199-209). Paris, France: Armand Colin.

Wang, H. (2005). 海归时代 [Returning times]. Beijing, China: Central Compilation \& Translation Press.

Wang, H. (2007). 当代中国海归 [Contemporary Chinese Returnees]. Beijing, China: China Development Press.

Wang, H. (2009). 中国留学人才发展报告[The report on the development of Chinese overseas educated talents]. Beijing, China: China Machine Press.

Wang, H. (2012). 中国留学发展报告 [Annual report on the development of study abroad in China] (Vol. 1). Beijing, China: Social Sciences Academic Press. 
Welch, A. R., \& Cai, H. (2011). Enter the Dragon: The internationalization of China's higher education system. In J. Ryan (Ed.), China's higher education reform and internationalization (pp. 9-33). Abingdon, UK: Routledge.

Welch, A. R., \& Hao, J. (2013). Returnees and diaspora as source of innovation in Chinese higher education. Frontiers of Education in China, 8(2), 214-238. doi: 10.3868/s110002-013-0016-7

Welch, A. R., \& Hao, J. (2014). 'Hai Gui'and 'Hai Dai': The job-seeking experiences of highskilled returnees to China. In K. H. Mok \& K. M. Yu (Eds.), Internationalization of higher education in East Asia: trends of student mobility and impact on education governance (pp. 90-114). Abingdon, UK: Routledge.

Welch, A. R., \& Zhen, Z. (2008). Higher education and global talent flows: Brain drain, overseas Chinese intellectuals, and diasporic knowledge networks. Higher Education Policy, 21(4), 519-537.

Williams, A. M., \& Baláž, V. (2012). Migration, risk, and uncertainty: Theoretical perspectives. Population, Space and Place, 18(2), 167-180. doi: 10.1002/psp.663

Wingens, M., de Valk, H., Windzio, M., \& Aybek, C. (2011). The sociological life course approach and research on migration and integration. In M. Wingens, M. Windzio, H. de Valk \& C. Aybek (Eds.), A life-course perspective on migration and integration (pp. 126). Heidelberg, Germany: Springer.

Xiang, B. (2003). Emigration from China: A sending country perspective. International Migration, 41(3), 21-48.

Xiang, B. (2011). A ritual economy of 'talent': China and overseas Chinese professionals. Journal of Ethnic and Migration Studies, 37(5), 821-838.

Xiao, S. (2004, August). "Return to China or Remain in the U.S.?" Gendered settlement preferences among Chinese students in the U.S. Paper presented at the Annual meeting 
of the American Sociological Association, San Francisco, CA. Retrieved from http://www.allacademic.com/meta/p109486_index.html

Yan, Y. (2010). The Chinese path to individualization. The British Journal of Sociology, 61(3), 489-512. doi: 10.1111/j.1468-4446.2010.01323.x

Zetter, R. (1999). Reconceptualizing the myth of return: Continuity and transition amongst the Greek-Cypriot refugees of 1974. Journal of Refugee Studies, 12(1), 1-22. doi: $10.1093 / \mathrm{jrs} / 12.1 .1$

Zhang, L., \& ONG, A. (Eds.). (2008). Privatizing China: Socialism from afar. Ithaca, NY: Cornelle University Press.

Zinn, J.O. (2004). Literature review: Sociology and risk. SCARR working paper 2004/1. University of Kent. Canterbury, UK. Retrieved from http://www.kent.ac.uk/scarr/papers/Sociology\%20Literature\%20Review\%20WP1.04 \%20Zinn.pdf

Zinn, J. O., \& Taylor-Gooby, P. (2006). Risk as an interdisciplinary research area. In P. TaylorGooby \& J. O. Zinn (Eds.), Risk in social science (pp. 20-53). Oxford, UK: Oxford University Press.

Zweig, D. (2006). Competing for talent: China's strategies to reverse the brain drain. International Labour Review, 145(1-2), 65-90. doi: 10.1111/j.1564913X.2006.tb00010.x

Zweig, D., \& Chen, C. (1995). China's brain drain to the United States: Views of overseas Chinese students and scholars in the 1990s. Berkeley, CA: Institute of East Asian Studies.

Zweig, D., Fung, C. S., \& Han, D. (2008). Redefining the brain drain : China’s ‘diaspora option’. Science Technology \& Society, 13(1), 1-33. doi: 10.1177/097172180701300101 
${ }^{1}$ I wish to express my gratitude to Professor Michalis Lianos for his unfailing encouragement and his very valuable suggestions, which helped in the development of some of the ideas in this chapter. I thank Mrs. Frédérique Menant and Mrs. Gyongyer Demeny for their generous assistance and advice during the preparation of the manuscript. Any remaining errors or omissions are the responsibility of the author alone.

${ }^{2}$ The Chinese household registration that determines eligibility for social benefits, including schooling for one's child. 